Research Paper

\title{
Fluorine Plasma Corrosion Resistance of Anodic Oxide Film Depending on Electrolyte Temperature
}

\author{
Jae-Soo Shin ${ }^{\mathrm{a}}$, Minjoong Kim ${ }^{\mathrm{a}}$, Je-beom Song ${ }^{\mathrm{b}}$, Nak-gwan Jeong ${ }^{\mathrm{b}}$, Jin-tae Kim ${ }^{\mathrm{b}, \boldsymbol{c} *}$, and Ju-Young Yun ${ }^{\mathrm{b}, c_{*}}$ \\ ${ }^{a}$ DaeJeon University, Daejeon 34520, Republic of Korea \\ ${ }^{b}$ Korea Research Institute of Standards and Science, Daejeon 34113, Republic of Korea \\ ${ }^{c}$ University of Science and Technology, Daejeon 34113, Republic of Korea
}

Received December 19, 2017; revised January 25, 2018; accepted January 25, 2018

\begin{abstract}
Samples of anodic oxide film used in semiconductor and display manufacturing processes were prepared at different electrolyte temperatures to investigate the corrosion resistance. The anodic oxide film was grown on aluminum alloy 6061 by using a sulfuric acid $\left(\mathrm{H}_{2} \mathrm{SO}_{4}\right)$ electrolyte of $1.5 \mathrm{M}$ at $0^{\circ} \mathrm{C}, 5^{\circ} \mathrm{C}, 10^{\circ} \mathrm{C}, 15^{\circ} \mathrm{C}$, and $20^{\circ} \mathrm{C}$. The insulating properties of the samples were evaluated by measuring the breakdown voltage, which gradually increased from $0.43 \mathrm{kV}\left(0^{\circ} \mathrm{C}\right)$ to $0.52 \mathrm{kV}\left(5^{\circ} \mathrm{C}\right), 1.02 \mathrm{kV}\left(10^{\circ} \mathrm{C}\right)$, and $1.46 \mathrm{kV}\left(15^{\circ} \mathrm{C}\right)$ as the electrolyte temperature was increased from $0^{\circ} \mathrm{C}$ to $15^{\circ} \mathrm{C}$, but then decreased to $1.24 \mathrm{kV}\left(20^{\circ} \mathrm{C}\right)$. To evaluate the erosion of the film by fluorine plasma, the plasma erosion and the contamination particles were measured. The plasma erosion was evaluated by measuring the breakdown voltage after exposing the film to $\mathrm{CF}_{4} / \mathrm{O}_{2} / \mathrm{Ar}$ and $\mathrm{NF}_{3} / \mathrm{O}_{2} / \mathrm{Ar}$ plasmas. With exposure to $\mathrm{CF}_{4} / \mathrm{O}_{2} / \mathrm{Ar}$ plasma, the breakdown voltage of the film slightly decreased at $0^{\circ} \mathrm{C}$, by $0.41 \mathrm{kV}$; however, the breakdown voltage significantly decreased at $20^{\circ} \mathrm{C}$, by $0.83 \mathrm{kV}$. With exposure to $\mathrm{NF}_{3} / \mathrm{O}_{2} / \mathrm{Ar}$ plasma, the breakdown voltage of the film slightly decreased at $0^{\circ} \mathrm{C}$, by $0.38 \mathrm{kV}$; however, the breakdown voltage significantly decreased at $20^{\circ} \mathrm{C}$, by $0.77 \mathrm{kV}$. In addition, for the entire temperature range, the breakdown voltage decreased more when sample was exposed to $\mathrm{NF}_{3} / \mathrm{O}_{2} / \mathrm{Ar}$ plasma than to $\mathrm{CF}_{4} / \mathrm{O}_{2} / \mathrm{Ar}$ plasma. The decrease of the breakdown voltage was lower in the anodic oxide film samples that were grown slowly at lower temperatures. The rate of breakdown voltage decrease after exposure to fluorine plasma was highest at $20^{\circ} \mathrm{C}$, indicating that the anodic oxide film was most vulnerable to erosion by fluorine plasma at that temperature. Contamination particles generated by exposure to the $\mathrm{CF}_{4} / \mathrm{O}_{2} / \mathrm{Ar}$ and $\mathrm{NF}_{3} / \mathrm{O}_{2} / \mathrm{Ar}$ plasmas were measured on a real-time basis. The number of contamination particles generated after the exposure to the respective plasmas was lower at $5^{\circ} \mathrm{C}$ and higher at $0^{\circ} \mathrm{C}$. In particular, for the entire temperature range, about five times more contamination particles were generated with exposure to $\mathrm{NF}_{3} / \mathrm{O}_{2} / \mathrm{Ar}$ plasma than for exposure to $\mathrm{CF}_{4} / \mathrm{O}_{2} / \mathrm{Ar}$ plasma. Observation of the surface of the anodic oxide film showed that the pore size and density of the non-treated film sample increased with the increase of the temperature. The change of the surface after exposure to fluorine plasma was greatest at $0^{\circ} \mathrm{C}$. The generation of contamination particles by fluorine plasma exposure for the anodic oxide film prepared in the present study was different from that of previous aluminum anodic oxide films.
\end{abstract}

Keywords: Fluorine plasma, Anodizing, Sulfuric acid, In-situ particle monitoring, Electrolyte temperature

\section{Introduction}

The plasma etching process, in the semiconductor and display manufacturing processes, is a dry etching process using plasma to pattern electric circuits in a vacuum. This process is a preferred etching method, because it enables excellent minimum length and large-area uniformity in semiconductor devices. During the process, metal parts of the etch equipment are exposed to fluorine plasma, and thus generate contamination particles due to erosion and defects, contaminating the semiconductor substrate and reducing the process yield. To solve this problem, the corrosion resistance of the metal parts is improved through

*Corresponding author

E-mail: jyun@kriss.re.kr anodic oxidation, in which metallic materials are connected to an anode and dipped into an electrolyte to grow a porous oxide film through electric oxidation [1-6]. Anodic oxidation is a metal surface treatment technology frequently used in the industry due to its high reproducibility and the excellent physical and chemical durability of the resulting products. The electrolyte composition, temperature, and current density are important factors that determine the properties of the oxide film in anodic oxidation. In particular, anodic oxidation using sulfuric acid $\left(\mathrm{H}_{2} \mathrm{SO}_{4}\right)$ is less costly, enables rapid formation of thick anodic oxide films, and yields excellent physical properties [7,9]. Recently, with the increase of plasma-based process steps and the demand for high precision, studies have been continuously conducted on the properties of anodic oxide films [10]. However, in contrast to the long-term research on process conditions of 
anodic oxidation and structural and physical propertie, plasma corrosion resistance has not been sufficiently analyzed or reported.

In the present study, for the manufacturing of films having high corrosion resistance to fluorine plasma, the surface of the oxide films was controlled [11-16] by varying the temperature of the electrolyte and the corrosion of the film was observed after exposure to fluorine plasma. In particular, contamination particles generated by the exposure of an anodic oxide film to fluorine plasma were evaluated to represent an actual process. In addition, scanning electron microscopy (SEM) images of the films were acquired to observe changes of the surface structure depending on the temperature and the exposure to fluorine plasma.

\section{Experimental}

Film samples of aluminum 6061 alloy (Alfa Aesar, Table. 1) were prepared at a size of $300 \mathrm{~mm} \times 300 \mathrm{~mm}$. The samples were subjected to sonication for 30 minutes in ethanol (99.999\%) to clean the surface. In addition, to reduce the roughness of the sample surface, electropolishing was performed for $60 \mathrm{~s}$ at $25 \mathrm{~V}$ and $600 \mathrm{~s}$ at $20 \mathrm{~V}$ using an electrolyte prepared by mixing $1200 \mathrm{ml}$ of ethanol $(99.999 \%)$ and $300 \mathrm{~mL}$ of perchloric acid (60\%) (1:4) as a chiller to keep the temperature at $20^{\circ} \mathrm{C}$. The material for the cathode was SUS306; the distance to the anode was 80 $\mathrm{mm}$. Then, electrolyte polishing was performed on both sides of the samples, and the resulting samples were rinsed with water for $60 \mathrm{~s}$.

After the electrolyte polishing, the backsides of the samples were masked using PET tape. The electrolyte for anodizing was prepared by mixing $126 \mathrm{ml}$ of sulfuric acid and $1374 \mathrm{ml}$ of deionized water $(1.5 \mathrm{M})$. A CCA-1111 chiller (EYELA) was used to control the temperature of the electrolyte, and the anodizing was performed at $0^{\circ} \mathrm{C}, 5^{\circ} \mathrm{C}$, $10^{\circ} \mathrm{C}, 15^{\circ} \mathrm{C}$, and $20^{\circ} \mathrm{C}$ for $3600 \mathrm{~s}$ using a magnetic stirrer (300 rpm). The material for the cathode was SUS306; the distance to the anode was $80 \mathrm{~mm}$.

The breakdown voltage was measured using TOS-9201 equipment (KIKUSUI); the breakdown voltage was determined as the voltage at which a current of $4 \mathrm{~mA}$ flowed when the voltage was increased at a rate of $15 \mathrm{~V} /$

Table 1. Al6061 alloy Chemical analysis

\begin{tabular}{cc}
\hline \hline Element & $\mathrm{Wt} \%$ \\
\hline $\mathrm{Cu}$ & 0.278 \\
$\mathrm{Cr}$ & 0.130 \\
$\mathrm{Fe}$ & 0.143 \\
$\mathrm{Mg}$ & 0.962 \\
$\mathrm{Mn}$ & 0.015 \\
$\mathrm{Si}$ & 0.465 \\
$\mathrm{Ti}$ & 0.013 \\
$\mathrm{Zn}$ & 0.058 \\
\hline
\end{tabular}

Source Power(Max : $1 \mathrm{~kW})$ Matching Box $(50 \Omega)$

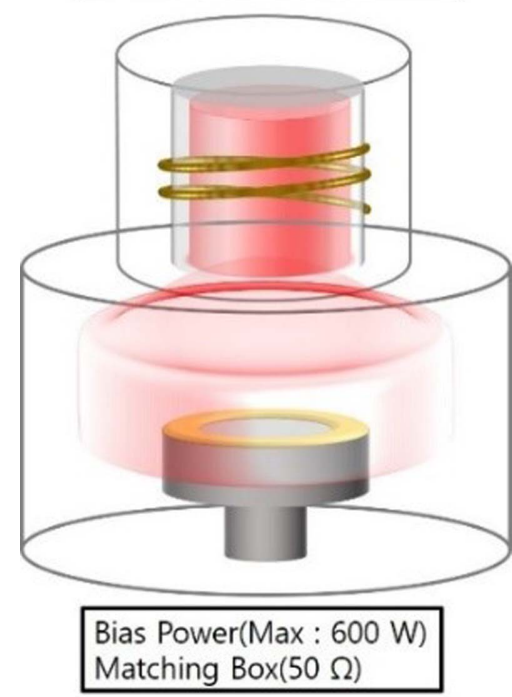

Figure 1. In-situ particle monitoring System (ISPM).

s (KS C 6521).

Changes of the surface were observed using an S-4800 field emission scanning electron microscope (FE-SEM, HITACH). The samples were exposed to plasma by using the Inductively Coupled Plasma-Reactive Ion Etching (ICP-RIE) device shown in Figure 1. The base pressure was $2.5 \mathrm{E}-6$ Torr; the working pressure was controlled at 3E-2 Torr. Two fluorine gases, $\mathrm{CF}_{4}$ and $\mathrm{NF}_{3}$, were respectively mixed with $\mathrm{O}_{2}$ and $\mathrm{Ar}$ at a mixing ratio of 6:5:1 to form the plasma. The top ICP power was $500 \mathrm{~W}$; the bottom bias power was $300 \mathrm{~W}$. The distance between the bottom sample loading position and the top ICP was $120 \mathrm{~mm}$.

The number of particles generated by the radical and physical reaction of $\mathrm{Al}_{2} \mathrm{O}_{3}$ on the sample surface due to the plasma exposure was measured using the in-situ particle monitoring system shown in Figure 2.

\section{Results and Discussion}

The thickness growth rate of the individual samples increased as the temperature of the electrolyte was increased, as shown in Figure 3.

Equations (1) and (2) are the formulae of the reactions occurring on the aluminum surface during the anodizing process.

$$
\left.\begin{array}{c}
2 \mathrm{Al}(s)+\frac{3}{2} \mathrm{O}_{2}(g) \rightarrow \alpha \mathrm{Al}_{2} \mathrm{O}_{3}(s) \\
; \Delta G^{\mathrm{o}}=-1582 \mathrm{kl} / \mathrm{mol}
\end{array}\right\}
$$






Figure 2. Schematic diagram of ICP-RIE equipment.

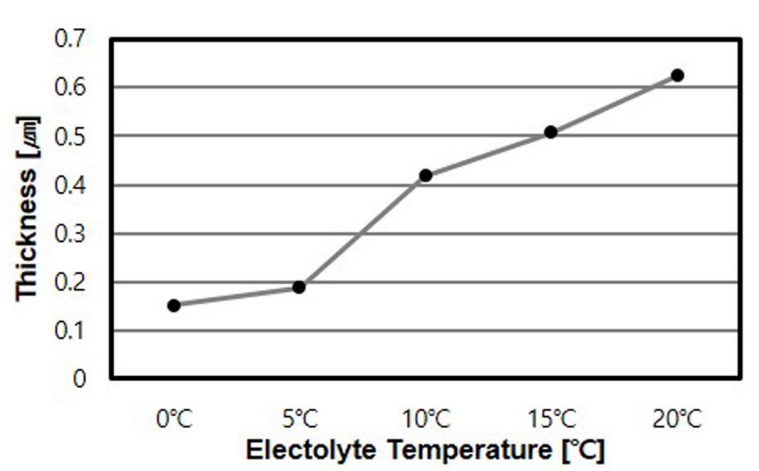

Figure 3. Growth of film thickness depending on electrolyte temperature.

The thickness of the aluminum oxide is determined by Faraday's Law, shown in Equation (3):

$$
t_{\mathrm{Al}_{2} \mathrm{O}_{3}}=\frac{17.6 I t}{\rho_{\mathrm{Al}_{2} \mathrm{O}_{3}} F}
$$

In Equation (3), $\rho_{\mathrm{Al}_{2} \mathrm{O}_{3}} F$ is the density of $\mathrm{Al}_{2} \mathrm{O}_{3}(3.62 \mathrm{~g} /$ $\left.\mathrm{cm}^{3}\right)$; $\mathrm{F}$ is the area of the aluminum surface $\left(\mathrm{cm}^{2}\right)$, I is current in coulmbs per second, $\mathrm{t}$ is time in second. The quantity of aluminum oxide is proportional to the quantity of electric charge passing through the electrolyte. The current density through the oxide film is defined as shown in Equation (4):

$$
j=j_{a}+j_{c}+j_{2}
$$

where $j_{a}, j_{c}$ and $j_{e}$ are the densities of the anions, cations, and electron-contributed current. Since the electric conductivity of aluminum oxide is extremely low, $j_{a}$ and $j_{c}$ are the major factors influencing the charge transfer. Therefore, as the electrolyte temperature increased during anodizing, the current increased. As a result, the current density affecting the oxide film growth also increased, as shown in Figure 4.

With the increase of the electrolyte temperature, the rate of film thickness growth increased as the current density increased from $228.6 \mathrm{~A} / \mathrm{m}^{2}\left(0^{\circ} \mathrm{C}\right)$ to $233.8 \mathrm{~A} / \mathrm{m}^{2}\left(5^{\circ} \mathrm{C}\right)$, $311.7 \mathrm{~A} / \mathrm{m}^{2}\left(10^{\circ} \mathrm{C}\right), 467.5 \mathrm{~A} / \mathrm{m}^{2}\left(15^{\circ} \mathrm{C}\right)$, and $545.5 \mathrm{~A} / \mathrm{m}^{2}$



Figure 4. Change of current density depending on electrolyte temperature.

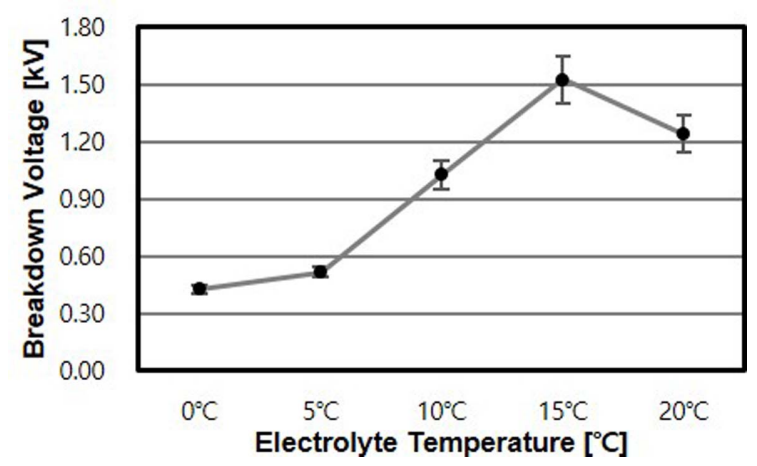

Figure 5. Breakdown voltage depending on electrolyte temperature.

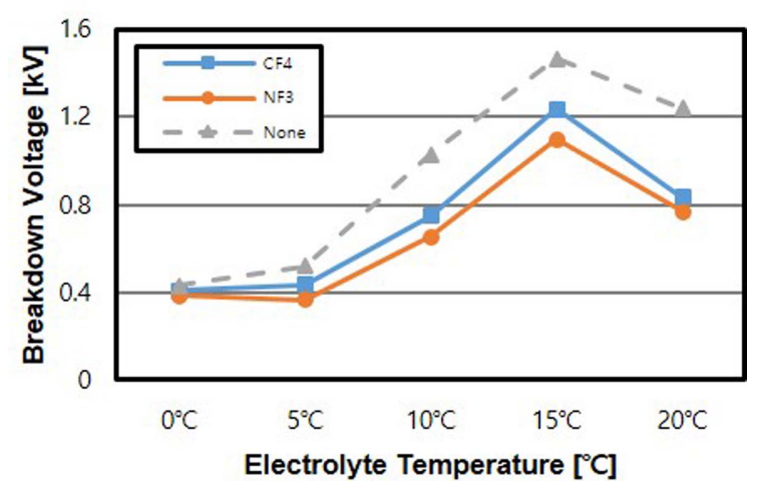

Figure 6. Decrease of breakdown voltage after exposure to fluorine plasma.

$\left(20^{\circ} \mathrm{C}\right)$.

Figure 5 shows the variation of the breakdown voltage depending on the electrolyte temperature. The breakdown voltage gradually increased from $0.43 \mathrm{kV}\left(0^{\circ} \mathrm{C}\right)$ to $0.52 \mathrm{kV}$ $\left(5^{\circ} \mathrm{C}\right), 1.02 \mathrm{kV}\left(10^{\circ} \mathrm{C}\right)$, and $1.46 \mathrm{kV}\left(15^{\circ} \mathrm{C}\right)$ as the electrolyte temperature increased from $0^{\circ} \mathrm{C}$ to $5^{\circ} \mathrm{C}, 10^{\circ} \mathrm{C}$, and $15^{\circ} \mathrm{C}$; the breakdown voltage then decreased to $1.24 \mathrm{kV}\left(20^{\circ} \mathrm{C}\right)$. This indicates that, because the current density was increased too rapidly, the anodic oxide film did not grow as a compact film.

To evaluate the plasma corrosion resistance, the samples were exposed to $\mathrm{CF}_{4} / \mathrm{O}_{2} / \mathrm{Ar}$ and $\mathrm{NF}_{3} / \mathrm{O}_{2} / \mathrm{Ar}$ plasmas; then, the breakdown voltages were measured, as shown in Figure 6. 


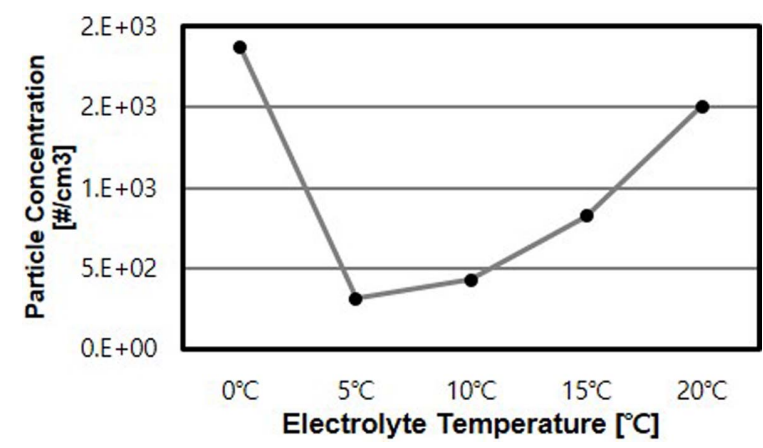

Figure 7. $\mathrm{CF}_{4} / \mathrm{O}_{2} / \mathrm{Ar}$ (6:5:1) plasma in-situ particles.

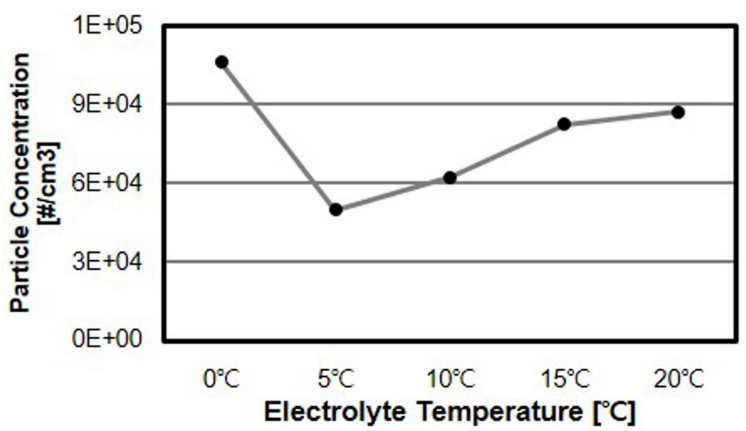

Figure 8. $\mathrm{NF}_{3} / \mathrm{O}_{2} / \mathrm{Ar}(6: 5: 1)$ plasma in-situ particles.
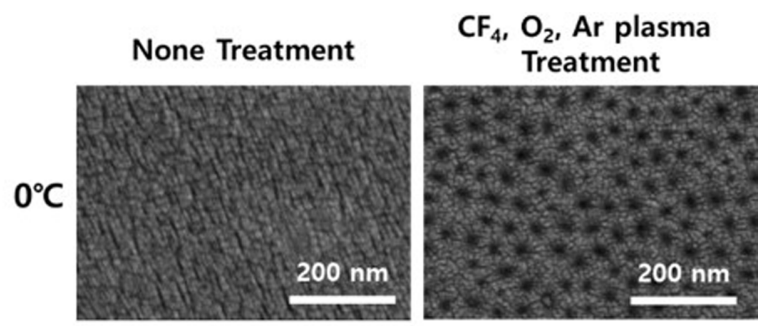

$5^{\circ} \mathrm{C}$
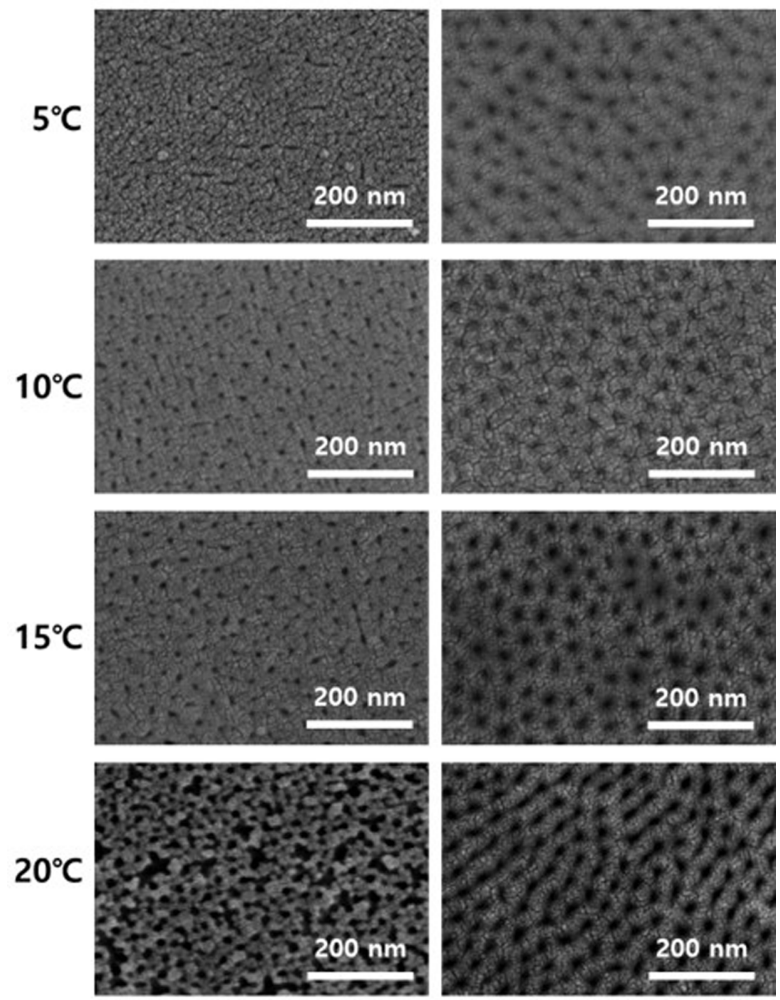

Figure 9. Change of the anodic oxide film surface depending on electrolyte temperature and exposure to $\mathrm{CF}_{4} / \mathrm{O}_{2} / \mathrm{Ar}$ plasma.

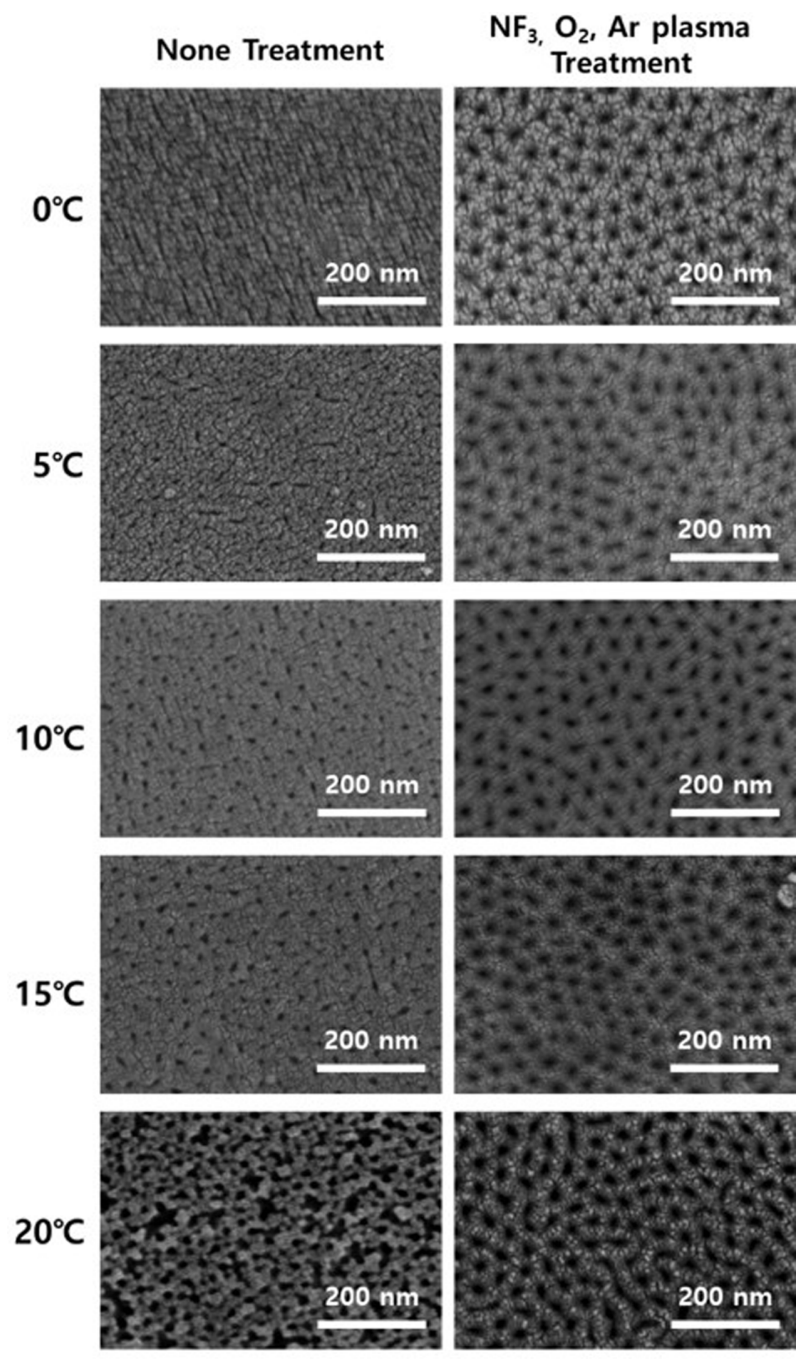

Figure 10. Change of anodic oxide film surface depending on electrolyte temperature and exposure to $\mathrm{NF}_{3} / \mathrm{O}_{2} / \mathrm{Ar}$ plasma.

With exposure to $\mathrm{CF}_{4} / \mathrm{O}_{2} / \mathrm{Ar}$ plasma, the breakdown voltage slightly decreased at $0^{\circ} \mathrm{C}$, by $0.41 \mathrm{kV}$; however, the breakdown voltage significantly decreased at $20^{\circ} \mathrm{C}$, by $0.83 \mathrm{kV}$. With exposure to $\mathrm{NF}_{3} / \mathrm{O}_{2} / \mathrm{Ar}$ plasma, the breakdown voltage slightly decreased at $0^{\circ} \mathrm{C}$, by $0.38 \mathrm{kV}$; however, the breakdown voltage significantly decreased at $20^{\circ} \mathrm{C}$, by $0.77 \mathrm{kV}$. In addition, for the entire temperature range, the breakdown voltage decreased more with exposure to $\mathrm{NF}_{3} / \mathrm{O}_{2} / \mathrm{Ar}$ plasma than with exposure to $\mathrm{CF}_{4} /$ $\mathrm{O}_{2} /$ Ar plasma. The decrease of the breakdown voltage was lower in the anodic oxide film samples that were grown slowly at a lower temperature. The rate of the breakdown voltage decrease after exposure to fluorine plasma was highest at $20^{\circ} \mathrm{C}$, indicating that the anodic oxide film was most vulnerable to erosion by fluorine plasma at that temperature.

Figures 7 and 8 show the number of contamination particles measured during exposure of the samples to the fluorine plasma. The numbers of the contamination particles were measured on a real-time basis while exposing the samples to the $\mathrm{CF}_{4} / \mathrm{O}_{2} / \mathrm{Ar}$ and $\mathrm{NF}_{3} / \mathrm{O}_{2} / \mathrm{Ar}$ 


\begin{tabular}{cc}
\hline \hline Element & $\mathrm{Wt} \%$ \\
\hline $\mathrm{Cu}$ & 0.278 \\
$\mathrm{Cr}$ & 0.130 \\
$\mathrm{Fe}$ & 0.143 \\
$\mathrm{Mg}$ & 0.962 \\
$\mathrm{Mn}$ & 0.015 \\
$\mathrm{Si}$ & 0.465 \\
$\mathrm{Ti}$ & 0.013 \\
$\mathrm{Zn}$ & 0.058 \\
\hline
\end{tabular}

plasmas, respectively. The number of contamination particles generated after exposure to the respective plasmas was lower at $5^{\circ} \mathrm{C}$ and higher at $0^{\circ} \mathrm{C}$, whether the samples were exposed to $\mathrm{CF}_{4} / \mathrm{O}_{2} / \mathrm{Ar}$ plasma or $\mathrm{NF}_{3} / \mathrm{O}_{2} / \mathrm{Ar}$ plasma. In particular, for the entire temperature range, about five times more contamination particles were generated with exposure to $\mathrm{NF}_{3} / \mathrm{O}_{2} / \mathrm{Ar}$ plasma than with exposure to $\mathrm{CF}_{4} /$ $\mathrm{O}_{2} /$ Ar plasma.

Figures 9 and 10 shows FE-SEM images of the sample surface. The pore size and density of the non-treatment $\mathrm{Al}_{2} \mathrm{O}_{3}$ film sample increased with the increase of the electrolyte temperature. In particular, the change of the surface structure was distinctive at $20^{\circ} \mathrm{C}$, indicating that the compactness of the structure decreased as the oxide film growth rate increased due to the increase of the current density on the surface. The pore size and density of the film surface exposed to $\mathrm{CF}_{4} / \mathrm{O}_{2} / \mathrm{Ar}$ plasma increased as the electrolyte temperature increased; the surface change was most prominent at $20^{\circ} \mathrm{C}$. The pores of the films surface changed more after exposure to $\mathrm{NF}_{3} / \mathrm{O}_{2} / \mathrm{Ar}$ plasma than they did after exposure to $\mathrm{CF}_{4} / \mathrm{O}_{2} / \mathrm{Ar}$ plasma. Due to the physicochemical actions of Ar ions and fluorine radicals, in comparison with the non-treatment samples, the pore size in the samples that underwent fluorine plasma treatment increased; this increase was highest at $20^{\circ} \mathrm{C}$.

\section{Conclusions}

In the preparation of the anodic oxide films, the pore size and density on the surface increased with the increase of the electrolyte temperature. The breakdown voltage gradually increased from $0.43 \mathrm{kV}\left(0^{\circ} \mathrm{C}\right)$ to $0.52 \mathrm{kV}\left(5^{\circ} \mathrm{C}\right)$, $1.02 \mathrm{kV}\left(10^{\circ} \mathrm{C}\right)$, and $1.46 \mathrm{kV}\left(15^{\circ} \mathrm{C}\right)$ as the electrolyte temperature was increased from $0^{\circ} \mathrm{C}$ to $5^{\circ} \mathrm{C}, 10^{\circ} \mathrm{C}$, and $15^{\circ} \mathrm{C}$; the breakdown voltage then decreased to $1.24 \mathrm{kV}$ $\left(20^{\circ} \mathrm{C}\right)$.

The breakdown voltage was measured after sample exposure to fluorine plasma. With exposure to $\mathrm{CF}_{4} / \mathrm{O}_{2} / \mathrm{Ar}$ plasma, the breakdown voltage slightly decreased at $0^{\circ} \mathrm{C}$, by $0.41 \mathrm{kV}$; however, it significantly decreased at $20^{\circ} \mathrm{C}$, by $0.83 \mathrm{kV}$. With exposure to $\mathrm{NF}_{3} / \mathrm{O}_{2} / \mathrm{Ar}$ plasma, the breakdown voltage slightly decreased at $0^{\circ} \mathrm{C}$, by $0.38 \mathrm{kV}$; however, the breakdown voltage significantly decreased at $20^{\circ} \mathrm{C}$, by $0.77 \mathrm{kV}$.

The number of contamination particles generated after the exposure to the respective plasmas was lower at $5^{\circ} \mathrm{C}$ and higher at $0^{\circ} \mathrm{C}$, whether the samples were exposed to $\mathrm{CF}_{4} / \mathrm{O}_{2} / \mathrm{Ar}$ or $\mathrm{NF}_{3} / \mathrm{O}_{2} / \mathrm{Ar}$ plasma. In particular, for the entire temperature range, about five times more contamination particles were generated with exposure to $\mathrm{NF}_{3} / \mathrm{O}_{2} / \mathrm{Ar}$ plasma than with exposure to $\mathrm{CF}_{4} / \mathrm{O}_{2} / \mathrm{Ar}$ plasma.

The results of the present study may be applied to reduce contamination particles generated from the anodic oxide film used for parts of semiconductors and display manufacturing equipment. Further study may be needed on contamination particles generated by exposure of anodic oxide film to a fluorine plasma environment.

\section{Acknowledgements}

This research was supported by the Development of Measurement Technology for Advanced Ultra-thin Film Processing program at the Korea Research Institute of Standards and Science, part of the R\&D Convergence Program of the National Research Council of Science and Technology (NST, No. CAP-16-04-KRISS)

\section{References}

[1] Huang, Yuelong, et al., Corrosion Science, 50(12), 3569-3575 (2008).

[2] Thamida, S. K., and Chang, H. C., Journal of Nonlinear Science, 12(1), 240-251 (2002).

[3] Lee, W., and Park, S. J., Chemical reviews, 114(15), 7487-7556 (2014).

[4] Zhang, J. S., Zhao, X. H., Zuo, Y., and Xiong,

[5] J. P., Surface and Coatings Technology, 202(14), 3149-3156 (2008).

[6] Huang, Y., Shih, H., Daugherty, J., and Mansfeld, F., Corrosion Science, 51(10), 2493-2501 (2009).

[7] Mansfeld, F., and Kendig, M. W., Journal of the Electrochemical Society, 135(4), 828-833 (1988).

[8] Masuda, H., Hasegwa, F., and Ono, S. Journal of the electrochemical society, 144(5), L127-L130 (1997).

Spooner, R. C., Journal of The Electrochemical Society, 102(4), 156162 (1955).

[9] Bradhurst, D. H., and Leach, J. L., Journal of The Electrochemical Society, 113(12), 1245-1249 (1966).

[10] Schwirn, K., Lee, W., Hillebrand, R., Steinhart, M., Nielsch, K., and Gösele, U., ACS nano, 2(2), 302-310 (2008).

[11] Aerts, T., Dimogerontakis, T., De Graeve, I., Fransaer, J., and Terryn, H., Surface and Coatings Technology, 201(16), 7310-7317 (2007).

[12] Chung, C. K., Liao, M. W., Chang, H. C., and Lee, C. T., Thin Solid Films, 520(5), 1554-1558 (2011).

[13] Sulka, G. D., and Parkoła, K. G., Electrochimica Acta, 52(5), 18801888 (2007).

[14] Chiu, R. L., Chang, P. H., and Tung, C. H., Thin Solid Films, 260(1), 47-53 (1995).

[15] Stępniowski, W. J., and Bojar, Z., Surface and Coatings Technology, 206(2), 265-272 (2011).

[16] Debuyck, F., Moors, M., and Van Peteghem, A. P., Materials chemistry and physics, 36(1-2), 146-149 (1993).

[17] Wang, L. P., Li, G., Liu, X. H., Xia, S. Y., and Jia, H. B., Journal of The Electrochemical Society, 164(6), E117-E122 (2017). 